\title{
Features of legal regulation of labor in the member states of the Eurasian Economic Union
}

\author{
T.A. Izbienova*, A.B. Vaiman, S.M. Sagitov \\ Kazan branch of Russian state University of justice, Kazan, Russian Federation
}

\begin{abstract}
In 2015, a new international integration economic association, the Eurasian Economic Union (hereinafter referred to as the EAEU), appeared on the economic and legal map of the world. Each member state of the EAEU, after gaining independence, as a result of the collapse of the USSR, independently formed a legislative framework in the field of labor, developed regulatory legal acts. Differences in the regulatory framework of the EAEU states, in particular, in the field of labor law, and their mutual economic integration, need to be compared in order to develop common principles, unification and harmonization of national legislation. In this regard, the article, based on the analysis of national labor legislation, assessed the prospects for regulating individual and collective labor relations and formulated conclusions on legal approaches to regulating social partnership relations, on the principles of the creation and functioning of trade unions and employers' associations in the EAEU countries. In particular, the trade unions of the post-Soviet republics that are part of the EAEU have completely lost the right of legislative initiative, which corresponds to global practice. Currently, they can only make proposals for the adoption, amendment of regulations related to their area of competence. The position of trade unions as social partners on the adoption and amendment of labor legislation has ceased to be mandatory, and is often not taken into account by employers and public authorities.
\end{abstract}

\section{Introduction}

The globalization as an objective process of interstate integration has an impact on the development of legal systems of modern states. The economic integration of the EAEU with the emergence of supranational institutions with the right to develop and adopt interstate regulations certainly affects the development of national labor law of each state of the Union.

It should be noted that the increased flows of labor migration have a great influence on the development of sources of labor law at the interstate level and at the level of an individual state. This is due to the globalization processes, the development of branch networks and the representation of international companies in different regions and countries of the world [1]. At the same time, one of the goals of the creation of the EAEU

\footnotetext{
* Corresponding author: nfnf1978@yandex.com
} 
is to create a common labor market with free movement of labor. In this regard, the unification of the basic principles of labor law plays a special role [2].

The need to study the legal regulation of labor relations in the countries of the Eurasian Economic Union (EAEU) is also due to the process of accelerating regional economic integration. Of course, economic integration is impossible without legal integration. This is due to the fact that the operation of legal norms is a factor ensuring the effective functioning of economies both within States and their associations in the international arena.

This study is aimed at finding and developing ways to harmonize the national labor laws of the EAEU member states.

\section{Theoretical bases. Methods}

The methodological basis of the research consists in the use of general scientific (dialectics, analysis and synthesis, abstraction and concretization) and private scientific research methods, primarily comparative legal, as well as formal legal, technical legal, legal modeling, historical legal, document analysis method.

\section{The results of study}

The development of collective labor law in the countries of the Eurasian Economic Union has a fairly short history. Its formation is connected with the collapse of the USSR, the emergence of democratic rights and freedoms, the development of entrepreneurship and the ability of workers to form and unite in trade unions. It is the trade unions, as some authors note, that are the main subject of collective labor law. During the Soviet period, trade unions were under strict state control and were in fact a quasi-state structure [3]. In the conditions of a planned socialist economy, where the state was the employer and the state was also the representative of employees, there could be no talk about the development and formation of collective labor law.

The Labor code of the Russian Federation doesn't clearly divide the subjects of labor law into collective and individual. Meanwhile, there is such a division in the legislation of other EAEU member states. Thus, the article 21 of the Labor code of the Republic of Kyrgyzstan establishes the classification of subjects of labor relations. The subjects of individual labor relations include the employee and the employer, the subjects of collective labor relations are the representative body of employees (trade union, united representative body, council of employees and others), employers' associations and other entities in cases provided for by laws.

The activity of trade unions in the EAEU countries is regulated by labor codes, special laws on trade unions of each state.

In the Republic of Armenia, the activities and legal status of trade unions are regulated by the Law «On Trade Unions». The subject of regulation of this law is the procedure for the establishment of the trade unions, the principles of their activities and relations with state bodies, local self-government bodies, legal entities and individuals, and also regulates relations related to the protection of the rights and interests of trade unions and their participants (members).

The term professional union in the Law of the Republic of Armenia is revealed through two independent terms. These are a professional organization and a union of professional organizations. A professional organization is understood as a public association that unites employees on the principle of voluntariness to represent and protect their labor and related social and other interests and rights. The Union of Professional Organizations, in turn, is a 
union of the legal entities that unites professional organizations and (or) unions of professional organizations.

The members of a professional organization may be persons working in the Republic of Armenia or abroad, including the foreign citizens and stateless persons. The military personnel and law enforcement officers can't be members of a professional organization. The ban is also imposed on an employer who can't hold leadership positions in a professional organization.

On the basis of the article 21 of the Law «On Trade Unions» of the Republic of Armenia, the trade unions are entitled to submit proposals to the Government of the Republic of Armenia and deputies of the National Assembly of the Republic of Armenia on the adoption of regulatory legal acts in the field of labor protection of workers.

In the Law of the Republic of Kazakhstan dated June 27, 2014 «On Trade Unions», the trade union is a public association with a fixed membership, voluntarily created on the basis of common labor, industrial and professional interests of citizens of the Republic of Kazakhstan to represent and protect the labor and socio-economic rights and interests of its members. The trade unions are created according to the industrial and sector principle.

They can unite on a territorial basis at the level of a district, city, region, city of republican significance, capital, and on an industry basis. They are independent of State and local self-government bodies, political parties, employers and their associations. They also have the right to international cooperation with trade unions from other states, to join associations, to conclude cooperation agreements. The law prohibits discrimination of employees for their participation in trade unions.

For example, the trade unions of the Republic of Kazakhstan have been granted the right to participate in the development of regulations affecting the labor and social rights of citizens. Among other things, they have the right to develop plans and programs for the social protection of workers, including programs to combat unemployment and ensure employment.

The Republic of Belarus also has its own Law «On Trade Unions». The Trade Union is a voluntary public organization uniting citizens of the Republic of Belarus, foreign citizens and stateless persons, including those studying in institutions of vocational, secondary specialized, higher education, connected by common interests in the field of activity in both industrial and non-industrial spheres, to protect labor, socio-economic rights and interests. The activity of trade unions may be restricted in cases provided for by the legislation of the Republic of Belarus in the interests of national security. The largest group of trade unions is the Federation of Trade Unions of Belarus, which unites more than $90 \%$ of the economically active population of the Republic.

Thus, trade unions in the EAEU countries are created on a voluntary basis of professional and industrial community to represent and protect the rights and interests of employees. They have a number of common rights. For example, the right to represent and protect the interests of employees, the conclusion of collective agreements, contracts, the right to information, the right to strike. At the same time, the trade unions of the postSoviet republics that are part of the EAEU have lost the right to legislative initiative, which corresponds to global practice. Currently, they can only make proposals for the adoption, amendment of regulations related to their area of competence. In our opinion, it is important that when developing regulatory legal acts in legislative bodies affecting the labor and socio-economic rights of citizens, projects should be sent to trade unions for approval.

The employers' associations are also subjects of collective labor law. At the same time, within the framework of the EAEU, two models of legal regulation of the employers' associations can be distinguished. Russia and the Kyrgyz Republic have a special law 
dedicated to employers' associations. Armenia, Belarus and Kazakhstan fix the rights and obligations in different legal acts.

The Federal Law of November 27, 2002 «On Employers' Associations» contains the definition of an employers' association, which means a type of association (union) based on voluntary membership of employers (legal entities and (or) individuals) and (or) employers' associations.

The employers' association has the right to represent and defend the rights of the members of the association, to initiate collective bargaining, to conclude agreements on behalf of the members of the association, to monitor the implementation of agreements and other rights.

The Law of the Kyrgyz Republic of May 22, 2004 «On Employers' Associations» stipulates that the employers' association is a non-profit organization based on the membership of employers.

The Labor code of the Republic of Armenia establishes that the employers' association acts as the representative of employers in collective labor relations. The Association, as in Russia and Kyrgyzstan, is a non-profit organization uniting employers.

The Labor code of the Republic of Belarus in Article № 355 reveals the concept of an association of employers who represent employers at the sector, republican and territorial levels.

In the Republic of Kazakhstan, the representatives of employers at the republican level are representatives of the National Chamber of Entrepreneurs of the Republic of Kazakhstan, the Republican Union of Associations of private entrepreneurship Entities, the Republican association for small Entrepreneurship, republican branch associations of private entrepreneurship entities.

The employers' association, as well as the employees' association, aren't 't a party to the social partnership, but only a representative. As noted by L.A. Ivanova and P.N. Kirichek, the functions of subjects of the social partnership in direct contacts with the other party are usually performed by representatives determined by them, who receive the right and are obliged to defend the interests of the party [4]. In addition, the party bearing the burden of material obligations is directly the employer in the case of a collective agreement or contract. The representatives of the employers' association will be subject of the social partnership, but not its party [5]. In other words, the obligations to ensure appropriate working conditions will be borne by the employer on whose behalf the agreement was concluded. The Employers' Association isn 't responsible for the obligations of its members.

\section{Discussion}

The labor market in the modern world is a reflection of socio-economic and political aspects of state regulation. The formation of the common labor market of the EAEU is taking place gradually. The basis of the formation is the merger of the national labor markets of each country.

The problems and prospects for the development of labor regulation within the EAEU are becoming particularly relevant at present for a number of reasons.

Firstly, the global market economy presupposes the development of international integration ties, especially with neighboring countries.

Secondly, the vast territory of the Russian Federation needs migrant workers, first of all, those specialties that are most in demand in modern Russian conditions.

Thirdly, the Russian Federation is interested in creating and expanding a common economic space with friendly neighboring countries. 
Fourth, labor regulation within the EAEU needs to be adjusted, since as a result of the viral pandemic, crisis phenomena are observed in the global economy, and unemployment is rising.

An important condition of the EAEU Treaty is the provision that employers in the territory of the Russian Federation have the right to employ foreign workers from the EAEU member states without taking into account the circumstances related to the protection of the national labor market. In the current situation, however, the protection of the national labor market is becoming an increasingly important task, since there is a sharp increase in unemployment worldwide, including in the Russian Federation, as a result of the coronavirus pandemic. However, the pandemic, the subsequent lockdown, and the development of digital technologies contribute to an increase in the number of workers involved in remote work. The chapter 49.1 of the Labor code of the Russian Federation is devoted to the regulation of remote labor. Meanwhile, the Republics of Armenia and Kyrgyzstan don't single out the remote labor separately.

The remote form of work has both positive and negative sides, both for employees and for employers. The employee can independently plan his working day, reduces the cost of moving to work. The employer shouldn't pay for the rent of the premises where the remote employee would work, or bear other costs for equipping the employee's work space. This falls on the shoulders of the employee himself. At the same time, the article 138 of the Labor code of the Republic of Kazakhstan contains a norm obliging the employer to provide the employee with means of communication (means of communication), as well as to bear the costs of their installation and maintenance. If the employee uses his own means of communication, the employer is obliged to compensate for the costs. This approach complies with European standards. By agreement of the parties, the remote worker may also be reimbursed for other expenses related to the performance of work for the employer (the cost of electricity, water and other expenses) [6]. At the same time, it is difficult for an employer to keep track of working hours and the effectiveness of remote work. In this regard, the opinion of O.G. Smirnova and G.V. Kazakova on the need to clarify the working time regime is fair [7].

The coronavirus pandemic and the introduction of the quarantine measures have actualized the issue of the remote labor regulation. In our opinion, within the framework of the EAEU, it is necessary to develop a common approach to the regulation of remote labor on the basis of the already existing regulatory framework of Russia, Kazakhstan and the European Union.

The establishment of restrictive quotas doesn`t apply to foreign workers from the EAEU member states, since this is in contradiction with Federal Law №115-FZ. On the basis of this law, quotas can be established only if foreign workers are required to apply for a visa before employment in the territory of the Russian Federation, and citizens from the EAEU member states do not apply for a visa on the basis of an Agreement.

Another important problem is the emergence of the shadow labor market. This is due to the lack of a unified regulatory framework in the field of labor regulation, protection of migrants' rights, differences in the social and economic policies of states and the volume of the labor market [8]. The shadow employment opens up an opportunity for migrant workers who have not found a place of official employment to work and earn money. In this case, employers get the opportunity to save on tax and other costs, and the employee has an income. However, informal employment also carries certain risks, both for the employer and for the employee. For the first, these are possible sanctions from the state, for the second, it is the uncertainty of working conditions, the absence of a guarantee of payment for work. To solve this problem, a unified policy should be developed to prevent the emergence of shadow employment. In particular, it is possible to reduce the tax burden on the sectors of the economy where informal migrant labor is most involved, and to develop 
common principles for combating shadow employment within the EAEU. Reducing the tax burden and bureaucratic barriers will allow a large number of companies to come to light, which will be more profitable to work according to the law than to be subjected to sanctions. At the same time, an increase in the number of such enterprises and a reduction in taxes will have a positive impact on state budget revenues. The liberalization of tax policy should be accompanied by a tightening of the employer's responsibility for shadow employment.

The integration of the labor market within the EAEU is accompanied by xenophobia. A change in the social environment leads to the weakening or breaking of social ties. The labor migrants unite in national diasporas. This helps them overcome the culture shock. However, in situations where national traditions are very different, there is a rejection of the cultural environment, adaptation is difficult. In this regard, it is necessary to create social institutions that will ensure the maximum adaptation of migrant workers. These can be cultural centers or social support centers established with national diasporas. The functional purpose of such centers is to provide professional training, eliminate the language barrier, and get acquainted with the culture of the host country. It is important to conduct educational events in the environment of the host country in order to convey information about the need for respectful attitude, peculiarities of behavior and adaptation of migrants to the social environment. Overcoming the above-mentioned problems is primarily associated with increasing the efficiency of managing the processes of Eurasian integration.

The development of a common labor market within the EAEU is impossible without the unification and harmonization of labor legislation, the development of common principles and approaches to the regulation of migrant labor, their rights, obligations and guarantees. The development of unified legislation should take place in cooperation with international organizations - the International Labor Organization, the International Organization for Migration. During their existence, a large number of model laws, recommendations, principles and concepts have been developed that will avoid the appearance of gaps in the law, facilitate the creation of unified legislation of the EAEU in the field of labor and take into account international experience. At the same time, the creation of a single labor market is facilitated due to the presence of historical experience within the USSR, the construction of economic zones, such as the Customs Union, the Single Economic Space. Within the framework of the activities of economic unions, agreements on cooperation in the field of regulation of migrant labor were developed. In this regard, it is important to ensure the continuity of existing experience, to use progressive norms.

Despite the comprehensively elaborated Treaty on the EAEU, there are some problems related to labor regulation within the framework of the Eurasian Economic Union. First of all, it should be noted that there are currently no effective mechanisms for monitoring the time of stay of foreign workers from the EAEU member states on the territory of Russia. The absence of such control complicates the collection of statistical data on the presence of foreign workers in the territory of the Russian Federation. In addition, foreign workers from the EAEU member states do not always indicate the purpose of their arrival in Russia, and the current legislation does not oblige them to specify their purpose. In the future, this may lead to a violation of the rights of foreign workers by employers who attract them to work.

It should be noted that only one of the four labor codes of the EAEU member states enshrines a conflict of laws rule on the priority of the labor code over other regulations. A conflict in labor law should be understood as a contradiction between the sources of legal regulation of labor relations, in other words, the presence of two or more existing legislative acts regulating one legal relationship in different ways. Meanwhile, the national laws on legislative acts of Belarus, Kazakhstan and Kyrgyzstan establish the possibility to 
give priority to the Labor code. Despite the consolidation of the priority of the Labor code in the Law on legislative acts, it is necessary to fix this norm in the Labor code itself. The Armenian legislation has a clear gap in this regard.

To resolve conflicts in the labor law of the EAEU member states, it is necessary to consolidate the principle of priority of the labor code over other national laws in the field of labor law and the priority of international legal acts over national ones.

There are other problems related to labor regulation within the EAEU. In particular, the idea of the need to create a single «pension space» by analogy with the single economic space is expressed in the special scientific literature. S.B. Aliyev points out the importance of signing an agreement on pension provision for foreign workers from the EAEU member states [9]. However, there are disagreements between the States on this issue based on the socio-economic policy of each state. Firstly, the life expectancy and population. The EAEU member states are divided into two groups: the negative dynamics in Russia, Belarus and Armenia, the positive dynamics in Kazakhstan and Kyrgyzstan. The life expectancy affects the retirement age set by the state. Secondly, the various inflation, which in turn affects the indexation of pensions. Thirdly, the level of pension burden. According to the severity of the pension burden, the EAEU states are also divided into two groups. The first is the countries with a low number of pensioners. It is Armenia, Kazakhstan, Kyrgyzstan (12$15 \%)$. The second is the countries with a high number. It is Russia, Belarus (25-30\%). Accordingly, Russia and Belarus have a high pension burden on the budget. Fourthly, the different level of GDP per capita and the rate of its growth, which affects the amount of payments and the scheme of their formation [10]. The pension provision of foreign workers should be based on the same principles as the pension provision of citizens of the country of employment. This concerns a number of issues: the acquisition and preservation of pension rights, payment of insurance premiums, accrual of retirement experience, pension points, etc.

This applies not only to pension provision, but also to the whole range of the rights and obligations of foreign workers. The prospects for the development of labor regulation within the framework of the Eurasian Economic Union primarily depend on the real provision of social and labor rights to foreign workers on an equal basis with citizens of the country of employment. The employers in some cases may violate these rights of foreign workers. In this regard, there is a problem of legal regulation of employers' activities in relation to foreign workers.

The policy aimed at the harmonization and unification of the labor legislation of the EAEU will sooner or later raise the issue of the development of pension legislation before the states. The development of economic integration is impossible without integration in the social sphere. Meanwhile, a draft Agreement on pension provision for workers of the EAEU member states has been developed. The draft Agreement provides for ensuring equal rights of workers of the EAEU member states with citizens of the state of employment. In addition, the proportional principle is fixed, i.e. each state pays for periods of work experience (formed rights) on its territory. Each Member State determines the right to a pension and calculates its amount in accordance with national legislation. In addition, the draft Agreement provides for the export of pensions. At the same time, in order to determine the right to a pension, it is provided for the summation of the insurance experience for the entire period of employment in the territory of the union. 


\section{Conclusion}

The conducted scientific research gives grounds to assert that the problems of legal regulation of labor in the EAEU member states is the lack of sufficient harmonization of the national legislation and unification of the basic principles of labor regulation.

The trade unions of the post-Soviet republics that are part of the EAEU have lost the right to legislative initiative, which corresponds to global practice. Currently, they can only make proposals for the adoption, amendment of regulations related to their area of competence. In our opinion, it is important that when developing regulatory legal acts in legislative bodies affecting the labor and socio-economic rights of citizens, projects should be sent to trade unions for approval.

The employers' association, as well as the employees' association, are not a party to the social partnership, but only a representative. The functions of the subjects of social partnership in direct contacts with the other party are usually performed by representatives determined by them, who receive the right and are obliged to defend the interests of the party. In addition, the party bearing the burden of material obligations is directly the employer in the case of a collective agreement or contract. The representatives of the employers' association and the association itself will be subjects of social partnership, but not its party. In other words, the obligations to ensure appropriate working conditions will be borne by the employer on whose behalf the agreement was concluded. The Employers' Association isn't responsible for the obligations of its members.

\section{References}

1. N. Lyutov, S. Golovina, Development of labor law in the EU and EAEU: how comparable? Russian Law Journal, 6, 93-117 (2018). DOI: https://doi.org/10.17589/2309-8678-2018-6-2-93-117

2. N. Lyutov, Russian Employment Protection: Analysis from the Perspective of EU Flexicurity Policy, International Journal of Comparative Labour Law and Industrial Relations, 28, 335-363 (2012)

3. N. L. Lyutov, Collective labor law of Great Britain: monograph (Moscow, Walters Kluver, 2009)

4. L. A. Ivanova, P. N. Kirichek, Social partnership: a new mode of being (Saransk, Red October, 2002)

5. S. J. Chucha, Social partnership in the labor sphere: the formation and development prospects of legal regulation in the Russian Federation: author's abstract, dis. Doctor of Law (specialty: 12.00.05) (Moscow, 2004)

6. A. K. Nadirova, On the issue of topical problems of the legal status of subjects of labor law, Russian Yearbook of Labor Law, 8, 553-563 (2013)

7. O. G. Smirnova, G. V. Kazakova, Employment contract with a teleworker: some issues, Bulletin of the Baltic Federal University. I. Kant. Series: Humanities and Social Sciences, 3, 142-147 (2014)

8. G. I. Osadchaya, Formation of the Eurasian Economic Union: ideas, reality, potential, Moscow (Publishing house «EconInform», 2019)

9. S. B. Aliev, Labor migration within the framework of the Eurasian Economic Union, Eurasian Economic Integration, 4(29), 65-71 (2015) 
10. S. V. Ryazantsev, A. A. Ter-Akopov, E. E. Pismennaya, M. N. Khramova, Scenarios for the development of the migration situation in the EAEU in the context of increased economic integration, Central Asia and the Caucasus, 19 (676), 8-19 (2017) 